\title{
The Etching of ZnO/Glass by Hydrogen Peroxide Solution: Surface Morphological, Structural, and Optical Properties
}

\author{
Mohd Zaki Mohd Yusoff ${ }^{1}$, Putri Nurin Irdina Mohd Ridza², Muhammad Syarifuddin Yahya ${ }^{3}$, \\ Md Rabiul Awal ${ }^{4}$ \\ ${ }^{1}$ Department of Applied Sciences, Universiti Teknologi MARA (UiTM) Cawangan Pulau Pinang, Jalan \\ Permatang Pauh, 13500 Permatang Pauh, Pulau Pinang, Malaysia, zaki7231@uitm.edu.my \\ ${ }^{2}$ Faculty of Chemical Engineering, Universiti Teknologi MARA (UiTM) Cawangan Pulau Pinang, Jalan \\ Permatang Pauh, 13500 Permatang Pauh, Pulau Pinang, Malaysia, putrinurinirdina24@ gmail.com \\ ${ }^{3}$ Faculty of Ocean Engineering Technology and Informatics, Universiti Malaysia Terengganu, 21030 Kuala \\ Nerus, Terengganu, Malaysia, syarif_yahya@umt.edu.my \\ ${ }^{4}$ Department of Electronics \& Instrumentation, Faculty of Ocean Engineering Technology and Informatics, \\ Universiti Malaysia Terengganu, 21030 Kuala Nerus, Terengganu, Malaysia, rabiulawal1@gmail.com
}

\begin{abstract}
This research was conducted to study the surface morphological, structural and optical properties of the samples after applying hydrogen peroxide $\left(\mathrm{H}_{2} \mathrm{O}_{2}\right)$ etching on Zinc Oxide $\mathrm{ZnO} /$ glass substrates. In order to fabricate $\mathrm{ZnO}$ thin film on the soda lime glass substrate, RF sputtering machine was used. The deposited layer of the $\mathrm{ZnO}$ thin film thickness was measured to be $1.218 \mu \mathrm{m}$. The $\mathrm{ZnO} / \mathrm{glass}$ samples were then immersed by the percentage of the hydrogen peroxide $\left(\mathrm{H}_{2} \mathrm{O}_{2}\right)$ concentrations which were $5 \%$ and $30 \%$ at the different time treatments. After immersing the samples into $30 \%$ concentration of $\mathrm{H}_{2} \mathrm{O}_{2}$ for 50 seconds, the result in SEM images showed the formation circles that resemble $\mathrm{ZnO}$ islands. The thickness of $\mathrm{ZnO}$ layer is reduced when the immersion time increases.
\end{abstract}

Key words : Zinc Oxide ( $\mathrm{ZnO})$, chemical wet etching, surface structure, hydrogen peroxide $\left(\mathrm{H}_{2} \mathrm{O}_{2}\right)$

\section{INTRODUCTION}

Zinc Oxide $(\mathrm{ZnO})$ is one of the tremendous semiconductor materials that are widely used in most of the electronic industry, for example, solar cells, photodetector, piezoelectric, LEDs, and lasers. Apart from that, $\mathrm{ZnO}$ is also used in the production of cosmetic, rubber, health supplements and many more [1]. As for the transparent $\mathrm{ZnO}$ film, it is one of the metal oxides in a part of semiconductor material groups and the bandgap of this inorganic sample is measured within an ultraviolet wavelength [2]. It consumes high energy bandgap, $3.37 \mathrm{eV}$ and larger binding energy. As for the $60 \mathrm{meV}$ of $\mathrm{ZnO}$ thin film, it is the key element of the great workable devices [3]. Various kind of glass substrates can be used in this kind of research such as quartz, fused silica, and soda lime glass. The soda lime glass is selected in this particular research due to its high optical transparency. Besides that, it is also a good insulator and cost-effective material [4]. Hydrogen peroxide $\left(\mathrm{H}_{2} \mathrm{O}_{2}\right)$ is generally used in the $\mathrm{ZnO}$ and $\mathrm{GaN}$ samples cleaning. Wang et al. (2014) reported that the enhancement of UV emission and surface uniformity of the etched- $\mathrm{ZnO}$ attributed to the various concentrations of $\mathrm{H}_{2} \mathrm{O}_{2}$ etchants [5]. While, Chen et al. (2005) revealed that the effects of luminescent characteristic and deep-level emission of $\mathrm{ZnO}$ are related to the $30 \%$ of the $\mathrm{H}_{2} \mathrm{O}_{2}$ concentration and $\mathrm{ZnO}$ surface, respectively [6]. Meanwhile, the immersion of $\mathrm{ZnO}$ nanorods on silicon substrate into the $30 \%$ hydrogen peroxide concentrations resulting in the oxygen desorption effect, luminescent characteristics increased, and moderately changed the structural property of the sample [7]. Meanwhile, for this study, $\mathrm{H}_{2} \mathrm{O}_{2}$ was selected due to its high availability. A part of, $\mathrm{H}_{2} \mathrm{O}_{2}$ being the high availability, it is also one of the good oxidizing agent with an excellent etching rate [5]. However, a report of $\mathrm{H}_{2} \mathrm{O}_{2}$ etching on $\mathrm{ZnO} /$ glass substrate is rarely found from the literature review. Hence, the surface morphological and structural qualities of the etched $\mathrm{ZnO}$ were investigated and the relationship between the resultants and etchant concentration was revealed. In this research, we reported that the fabrication of $\mathrm{ZnO}$ on a glass substrate was completed by $\mathrm{RF}$ sputtering machine. The etched $\mathrm{ZnO}$ islands were successfully formed by a simple $\mathrm{H}_{2} \mathrm{O}_{2}$ etching method.

\section{EXPERIMENTAL WORK}

In this particular research, the fabrication of the $\mathrm{ZnO}$ thin film on the soda lime glass was done using the RF sputtering machine. The glass substrate was cleaned by dipping the substrate into deionized water for 15 minutes and was dried by nitrogen blowing. The RF power and base pressure were set at $150 \mathrm{~W}$ and $3.54 \times 10^{-3} \mathrm{mbar}$, respectively. The $\mathrm{H}_{2} \mathrm{O}_{2}$ wet etching process was conducted to form etched $\mathrm{ZnO} /$ glass substrate. The deposited $\mathrm{ZnO}$ samples were dipped into $\mathrm{H}_{2} \mathrm{O}_{2}$ 
solution at different concentration (5\% and 30\%). The unwanted chemical moisture on the etched $\mathrm{ZnO}$ samples was rinsed and dried by a nitrogen air gun. The bandgap, the structural and the surface morphological were characterized by UV-spectroscopy, X-ray diffraction, scanning electron microscope (SEM), respectively. The captured SEM images were evaluated using Image $₫$ software for determining the diameter of each $\mathrm{ZnO}$ islands.

\section{RESULTS AND DISCUSSIONS}

The non-uniform shapes and sizes of $\mathrm{ZnO}$ islands were detected from all the samples as shown in Figure 1. The $30 \% / 100$ s sample showed the lowest decrement on the $\mathrm{ZnO}$ thickness compared to the other samples. The etched $\mathrm{ZnO}$ value had decreased simultaneously with the increasing of $\mathrm{H}_{2} \mathrm{O}_{2}$ concentration. The stable gas of $\mathrm{H}_{2} \mathrm{O}_{2}$ found continuously reducing the thickness of $\mathrm{ZnO}$ thin films. Non-uniform thicknesses of films were spotted from all samples. The average thickness of the samples (Figure 1) was calculated to be $1.218 \mu \mathrm{m}$ (as-deposited), $0.989 \mu \mathrm{m}(5 \% / 50 \mathrm{~s})$, $0.411 \mu \mathrm{m}(30 \% / 50 \mathrm{~s})$ and $0.386 \mu \mathrm{m}(30 \% / 100 \mathrm{~s})$. It can be seen that the thicknesses of the etched $\mathrm{ZnO}$ layer had decreased which is due to the $\mathrm{H}_{2} \mathrm{O}_{2}$ etching effect. The lower thickness of the etched $\mathrm{ZnO}$ layer is found from the sample 30\%/100s. The ImageJ ${ }^{\circledR}$ software was used to estimate the diameter of the $\mathrm{ZnO}$ islands formed on the glass substrate. Figure 2 indicates the filtered images of the $\mathrm{ZnO}$ islands on the glass substrate by using the ImageJ ${ }^{\circledR}$ software. Meanwhile, Table 1 shows the average diameter of $\mathrm{ZnO}$ islands on a glass substrate. Sample 5\%/50s, 30\%/50s, and 30\%/100s indicated the average diameter of $\mathrm{ZnO}$ islands as 1.477, 1.062, and $1.872 \mu \mathrm{m}$. The lowest diameter of $\mathrm{ZnO}$ islands is obtained from the sample $30 \% / 50 \mathrm{~s}$, while the sample $30 \% / 100 \mathrm{~s}$ showed the largest diameter of $\mathrm{ZnO}$ compared to the other samples.

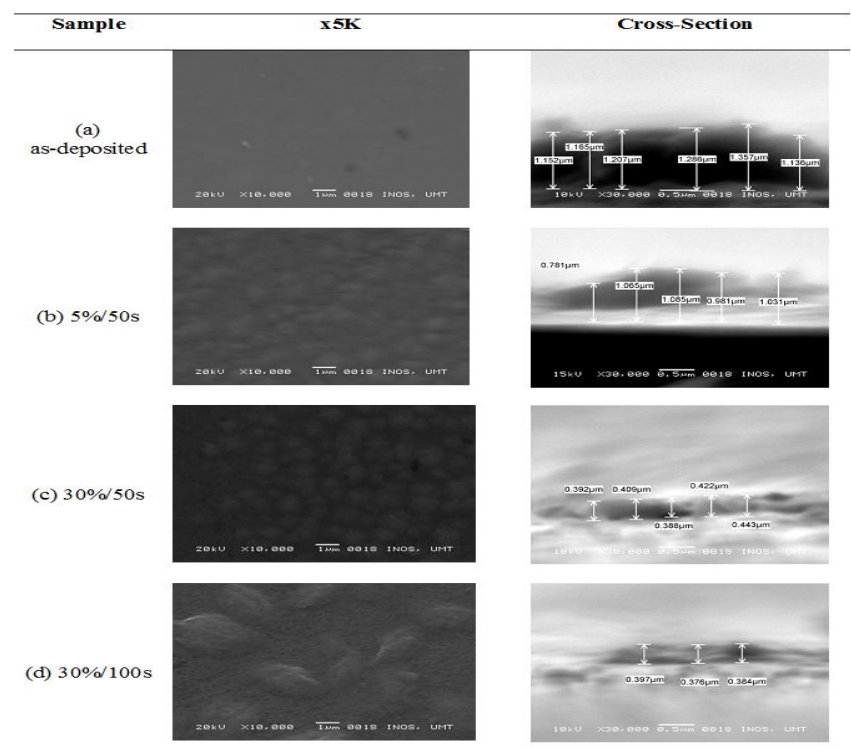

Figure 1: Top view and Cross-sectional SEM Images of $\mathrm{ZnO}$ films at different concentration.
For ImageJ ${ }^{\circledR}$ analysis, well-formed $\mathrm{ZnO}$ islands were spotted from sample 30\%/50s with larger spacing between islands. $\mathrm{H}_{2} \mathrm{O}_{2}$ is believed to generate more defects which relate to oxygen element [8]. After introducing an oxidizer for $\mathrm{H}_{2} \mathrm{O}_{2}$, the oxide layer is formed on the $\mathrm{ZnO}$ surface [9]. The etching mechanism of O-terminated surface is faster and uniform compared to the $\mathrm{Zn}$-terminated [10]. Moreover, at the $\mathrm{ZnO}$ surface, an oxidizer of $\mathrm{H}_{2} \mathrm{O}_{2}$ is reported to effectively remove $\mathrm{Zn}$ interstitials, $\mathrm{Zn}$ or $\mathrm{O}_{2}$ vacancies [11].
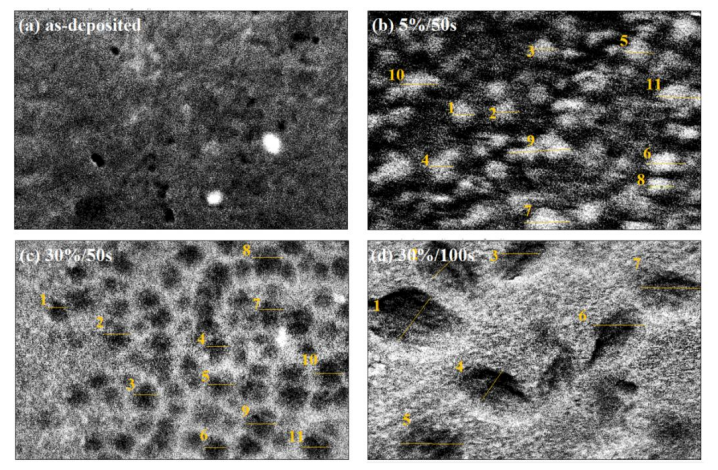

Figure 2: $\mathrm{ZnO}$ film images analyzed using the ImageJ software at different concentration.

Table 1: Average diameter of $\mathrm{ZnO}$ islands grown on glass substrate based on ImageJ analysis

\begin{tabular}{|c|c|}
\hline Sample & Average Diameter $(\boldsymbol{\mu m})$ \\
\hline as-deposited & - \\
\hline $5 \% / 50 \mathrm{~s}$ & 1.477 \\
\hline $30 \% / 50 \mathrm{~s}$ & 1.062 \\
\hline $30 \% / 100 \mathrm{~s}$ & 1.872 \\
\hline
\end{tabular}

The broad single peak at around $35.3^{\circ}$ was observed on all samples, showing that the $\mathrm{ZnO}$ films tended to grow on 101 crystal plane (refer Figure 3). The crystallite size of the samples was determined using the Scherrer's equation.

$\mathrm{D}=0.94 \lambda /(\beta \cos \theta)$

where $\lambda$ is the $X$-ray wavelength, $\theta$ is the diffraction angle and $\beta$ is the full width at half maximum (FWHM) of the $\mathrm{ZnO}$ peak value. The crystallite size value of $43.54,51.21$, and $48.37 \mathrm{~nm}$ were obtained from the sample as-deposited, 30\%-50s, and $30 \%-100 \mathrm{~s}$. A wide broader XRD peak of $\mathrm{ZnO}$, no crystallite size is calculated from the sample 5\%-50s. Sample 30\%-50s showed the highest crystallite size value compared to the other samples. The highest crystallite size value was reported from the well-formed $\mathrm{ZnO}$ islands on the glass substrate. Figure 4 indicates the optical transmittance of samples at different etching condition. All samples show the transmission of $80 \%$ and above in the visible range wavelength $(400-700 \mathrm{~nm})$. The transmittance of $\mathrm{ZnO}$ is increased with the decrement in $\mathrm{ZnO}$ thickness [12]. It can be observed that the sample 30\%/100s resulted in the highest transmission after the $550 \mathrm{~nm}$ wavelength due to the decrement of $\mathrm{ZnO}$ thickness. 
From the transmittance graph, the direct bandgap of $\mathrm{ZnO}$ is calculated by the Tauc equation as the following below.

$\alpha h v=A\left(h v-E_{b g}\right)^{1 / 2}$

where $\alpha, h, v, A$ and $\mathrm{E}_{\mathrm{bg}}$ are the optical absorption coefficient, the Planck's constant, the frequency of the incident photon, the constant for a direct transition (absorbance value) and the bandgap energy, respectively. In addition, the bandgap energy of $\mathrm{ZnO}$ films is calculated by considering the linear graph of an extrapolation $(\alpha h v)^{2}$ versus energy $h v$, as shown in Figure 5. The bandgap energy of $\mathrm{ZnO}$ films was measured to be $3.85 \mathrm{eV}$ (as-deposited), $3.83 \mathrm{eV}$ (5\%/50s), $3.29 \mathrm{eV}$ (30\%/50s) and $3.28 \mathrm{eV}(30 \% / 100 \mathrm{~s})$. The 30\%/100s sample showed the lowest bandgap energy compared with other samples. Ismail et. al reported lower bandgap energy of $\mathrm{ZnO}$ prepared by sol-gel method at around $3.27 \mathrm{eV}$ using the same calculation method [13]. On the hand, Azzafeerah et. al used potassium hydroxide $(\mathrm{KOH})$ to fabricate porous gallium nitride $(\mathrm{GaN})$ on a sapphire substrate [14]. As for future work, potassium hydroxide $(\mathrm{KOH})$ chemical etching will be used to make porous $\mathrm{ZnO}$ on a glass substrate. This future work is considered since the $\mathrm{ZnO}$ bandgap energy $(3.37 \mathrm{eV})$ is very close to $\mathrm{GaN}$ bandgap energy $(3.39 \mathrm{eV})$ and the structural property for both samples are similar.

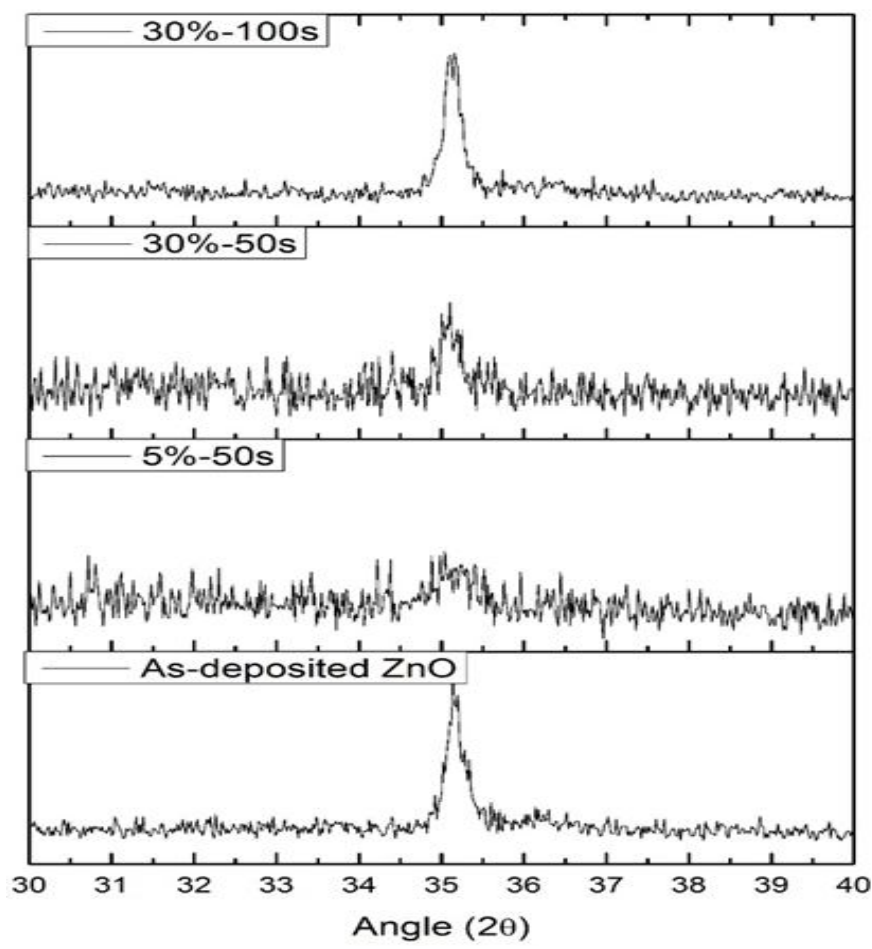

Figure 3: XRD diffraction of the studied samples for different $\mathrm{H}_{2} \mathrm{O}_{2}$ concentration.

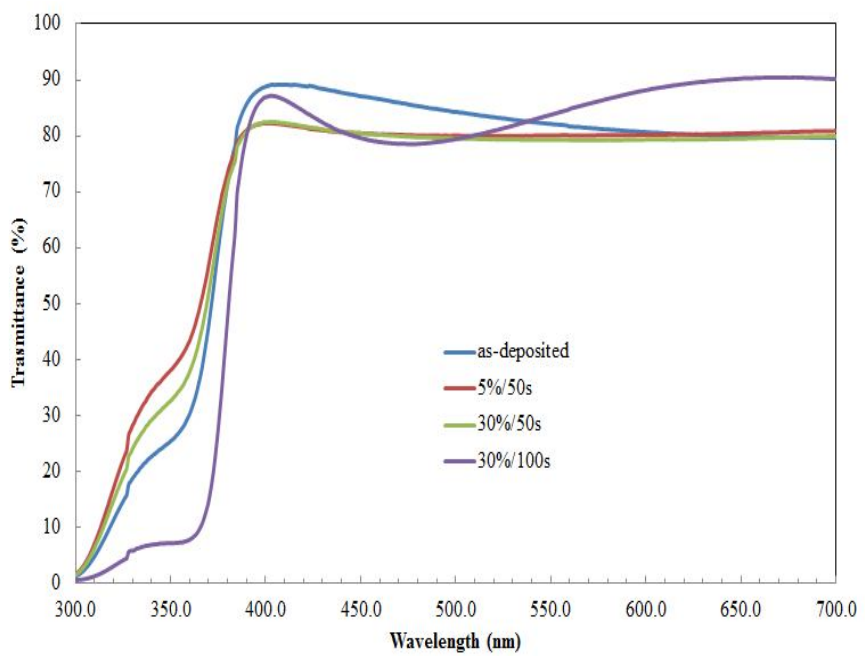

Figure 4: Optical transmittance spectra of the studied samples for different $\mathrm{H}_{2} \mathrm{O}_{2}$ concentration.

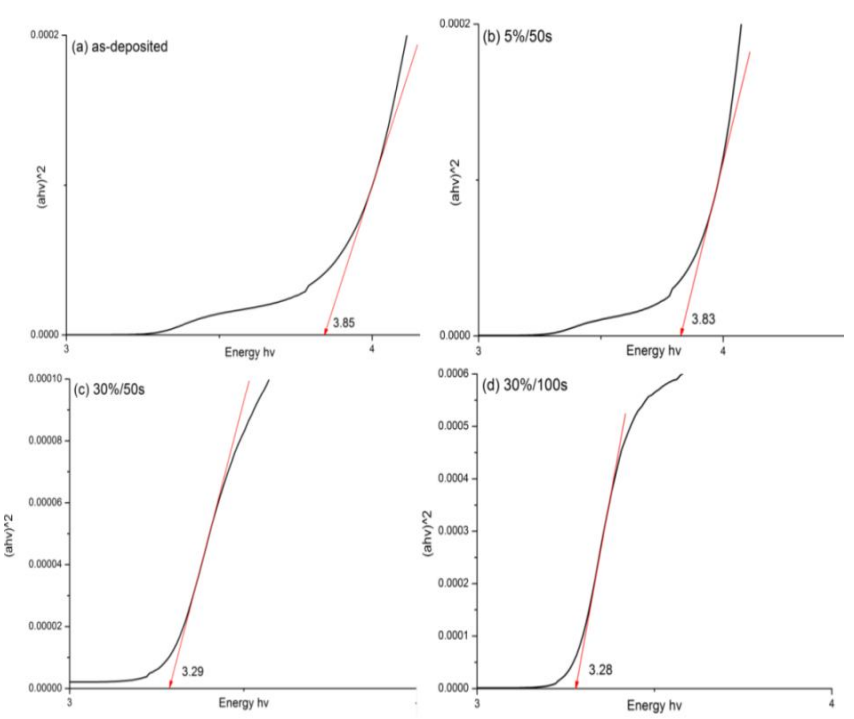

Figure 5: The Tauc plots of $(\alpha h v)^{2}$ versus energy $h v$.

\section{CONCLUSION}

The $\mathrm{ZnO}$ islands have been successfully formed with a simple wet chemical $\mathrm{H}_{2} \mathrm{O}_{2}$ etching. The SEM characterization showed that the higher $\mathrm{H}_{2} \mathrm{O}_{2}$ concentration had significantly reduced the average thickness of the $\mathrm{ZnO}$ thin film but had the largest $\mathrm{ZnO}$ islands grown on the glass substrate. Meanwhile, the XRD characterization had confirmed that all the studied $\mathrm{ZnO}$ samples were grown on 101 crystal plane. Furthermore, the highest $\mathrm{H}_{2} \mathrm{O}_{2}$ concentration resulting in the highest transmittance value due to the decrement of $\mathrm{ZnO}$ thickness. As for the calculated bandgap energy, the thinnest $\mathrm{ZnO}$ film (highest $\mathrm{H}_{2} \mathrm{O}_{2}$ concentration) gave the lowest value which was $3.28 \mathrm{eV}$. 


\section{ACKNOWLEDGEMENT}

Mohd Zaki Mohd Yusoff would like to thank Universiti Teknologi MARA (UiTM) Cawangan Pulau Pinang, Malaysia that supports this work. Meanwhile, Muhammad Syarifuddin Yahya would like to thank Universiti Malaysia Terengganu for the support and the equipment provided.

\section{REFERENCES}

1. K. H. Shim, J. Hulme, E. H. Maeng, M. K. Kim, and S. S. A. An. Analysis of zinc oxide nanoparticles binding proteins in rat blood and brain homogenate, Int. J. Nanomedicine, Vol.9 (Suppl 2), pp.217-224, 2014. https://doi.org/10.2147/IJN.S58204

2. I. S. Jeong, J. H. Kim, and S. Im. Ultraviolet-enhanced photodiode employing n-ZnO/p-Si structure, Appl. Phys. Lett., Vol.83 (14), pp.2946-2948, 2003. https://doi.org/10.1063/1.1616663

3. Kumar, Vinod, H. C. Swart, O. M. Ntwaeaborwa, R. E. Kroon, J. J. Terblans, S. K. K. Shaat, A. Yousif, and M. $M$. Duvenhage. Origin of the red emission in zinc oxide nanophosphors, Mater. Lett., Vol. 101, pp.57-60, 2013. https://doi.org/10.1016/j.matlet.2013.03.073

4. A. Sharma, and S. Aggarwal, S. Optical investigation of soda lime glass with buried silver nanoparticles synthesised by ion implantation, J. Non-Cryst. Solids, 485, pp.57-65, 2018. https://doi.org/10.1016/j.jnoncrysol.2018.01.038

5. Y. Wang, T. Wu, M. Chen, L. Su, Q. Zhang, L. Yuan, Y. $\mathrm{Zhu}$ and $\mathrm{Z}$. Tang. Well-controlled wet etching of $\mathrm{ZnO}$ films using hydrogen peroxide solution, Appl. Surf. Sci., 292, pp.34-38, 2014.

6. Y. Chen, L. Wang, C. Mo, Y. Pu, W. Fang, and F. Jiang. Study of structural and luminescent properties of high-quality $\mathrm{ZnO}$ thin films treatment with hydrogen peroxide solution, Mater. Sci. Semicond. Process., Vol. 8(5), pp.569-575, 2005.

7. W. Y. Su, J. S. Huang, and C. F. Lin. Improving the property of $\mathrm{ZnO}$ nanorods using hydrogen peroxide solution, J. Cryst. Growth, 310(11), pp.2806-2809, 2008. https://doi.org/10.1016/j.jcrysgro.2008.01.040

8. C. H. Tsai, C. I. Hung, C. F. Yang, and M. P. Houng. Hydrogen peroxide treatment on $\mathrm{ZnO}$ substrates to investigate the characteristics of $\mathbf{P t}$ and $\mathbf{P t}$ oxide Schottky contacts, Appl. Surf. Sci., Vol. 257(2), pp.610-615, 2010.

9. E. Y. Chang, Y. L. Lai, Y. S. Lee, and S. H. Chen. A GaAs/AlAs wet selective etch process for the gate recess of GaAs power metal-semiconductor field-effect transistors, J. Electrochem. Soc., 148(1), pp.G4-G9, 2001.

10. W. Jo, S. J. Kim, and D. Y. Kim. Analysis of the etching behavior of $\mathrm{ZnO}$ ceramics, Acta Materialia, Vol. 53(15), pp.4185-4188, 2005. https://doi.org/10.1016/j.actamat.2005.05.017

11. S. H. Kim, H. K. Kim, and T. Y. Seong. Effect of hydrogen peroxide treatment on the characteristics of Pt Schottky contact on n-type ZnO, Appl. Phys. Lett., Vol. 86(11), pp.112101, 2005. https://doi.org/10.1063/1.1862772

12. J. Yoo, J. Lee, S. Kim, K. Yoon, I.J. Park, S.K. Dhungel, B. Karunagaran, D. Mangalaraj, and J. Yi. High transmittance and low resistive $\mathrm{ZnO}$ : Al films for thin film solar cells, Thin Solid Films, Vol. 480, pp.213-217, 2005

13. A.S. Ismail, M.H. Mamat, M.M. Yusoff, M.F. Malek, A.S. Zoolfakar, R. Mohamed, N.D. Md. Sin, W.R.W. Ahmad, A.B. Suriani, M.K. Ahmad, I.B. Shameem Banu, and M. Rusop. Structural, Optical, and Humidity Sensing Performance of Pb-Doped Zno Nanostructure Prepared by Sol-Gel Immersion Method, International Journal of Advanced Trends in Computer Science and Engineering, Vol. 8, No.1.3, pp.166-170, 2019

14. Azzafeerah Mahyuddin, Ashraf Rohanim Asari, Azrina Arshad, Mohd Zaki Mohd Yusoff. Effect of KOH Concentration on the Properties of Undoped Porous GaN on Sapphire Substrate Prepared by UV assisted Electrochemical Etching, International Journal of Advanced Trends in Computer Science and Engineering, Vol. 9, No.1.1, pp.246-251, 2019 https://doi.org/10.30534/ijatcse/2020/4491.12020 